UDC: 339.138:502.3

DOI: 10.31651/2076-5843-2019-1-144-150

Pimonenko Tetyana,

$\mathrm{PhD}$, Associate Professor,

Economics, Entrepreneurship and Business

Administration Department,

Sumy State University

Orcid: https://orcid.org/0000-0001-6442-3684

tetyana.pimonenko@gmail.com

Chygryn Olena,

PhD, Associate Professor,

Economics, Entrepreneurship and Business

Administration Department,

Sumy State University

Orcid: https://orcid.org/0000-0002-4007-3728

Lyulyov Oleksii Dr,

Associate Professor,

Economics, Entrepreneurship and Business

Administration Department,

Sumy State University

Orcid: https://orcid.org/0000-0002-4865-7306

\title{
GREEN BRANDING AS A DRIVER TO BOOST THE DEVELOPMENT OF GREEN INVESTMENT MARKET
}

The paper deals with the analysis of the main preconditions to develop the strategy of the green brand promotion with the purpose to attract additional green investment to the company's development. In this case, the authors allocated the main features of green investment which should be taken into account during the developing of the marketing program to promote the green brand of the company. The authors identified the main approaches to define the meaning of a green brand. Thus, in the paper, the authors defined the green brand as the unique symbols, signs, words or combinations of them which developed the green imagination about the company which operations correspond to the sustainable development goals. In the paper, the authors allocated the main drivers of the green brand as follows: green brand equity, green trust and green satisfaction. Besides, green brand equity has a mediating role between green trust and green satisfaction. With the purpose to increase the efficiency of the marketing program to promote green brand the authors generalized the main principals which should be considered by the companies. The authors highlighted that using greenwashing lead to the huge reputation loses. Besides, greenwashing decreases the level of trust to the green brand among stakeholders of the green investment market. The authors proposed to solve the abovementioned problem through the publication in free access to the nonfinancial report by the company on a regular basis. In addition, it should be obligatory and to control by the government. In the paper, the theoretical basis of the linking between sustainability, green brand perception and company policy performance was identified by the authors.

Keywords: investment; marketing; green; stakeholders; brand; promotion; added value.

Introduction. The increasing conscious of environmental problems among society provoke companies to reorient their activities according to the green needs of consumers. At the same time, the ongoing mainstream among investors to invest in green goals justify developing and promoting the green images and green brand by the companies. Thus, the positive company's green brand and high level of consumers loyalty allow attracting additional finance as the green investment into the company's development. Thus, the companies which listed by the green stock indexes have a higher added value. Experience of EU countries showed that green investment is the new perspective market which characterised by the rapid increasing from year to year. Noted, that ongoing economic and political conflicts have a negative impact on the country's brand and image. As a consequence, 
it leads to decreasing of the country's investment climate which limits the developing of the national green investment market. And companies don't have the huge options to attract additional green investment in their development. In this case, it is necessary to develop and to implement the effective mechanism to promote the green brand as at the country level as at the company's level.

Literature review. The results of the analysis of the scientific papers and investigations on green branding proved that green branding as the instrument for attracting green investment is the modest direction. The analysis and systematization of approaches to defining green branding, green investment showed that the universal definitions have not developed which were recognized by the worldwide scientific community. Thus, under this research, the green investment defined as the investment which invests in green assets. In this case, green assets mean the assets which provoke the mitigation of the negative impact of climate changes on the environment. Thus, the main features of green investment are an orientation to green goals and corresponding with the sustainable development goals $[16,18]$. Thus, if companies try to attract the additional green investment it should be used the relevant marketing program to develop the green brand of the company. In this case, the green brand concept should consider the features of green investment stakeholders.

According to the traditional market concept, the brand is defined as a unique symbol, signs, words or combination of them which developed the imagination about the company or product. Thus, adding the green features to the traditional definitions, the green brand could be determined as a unique symbol, signs, words or combination of them which developed the green imagination about the company which operations correspond to the sustainable development goals. Thus, the scientists Hartmann P., Forcada Sainz F. J., Mourad M., Ahmed Y. S., Matthes J., Wonnerberger A. and D. Schmuck in the papers $[8,9,10]$ defined green brand as the marketing communication and differentiation of the brand from its competitors through its environmentally features. The huge range of scientists in the papers $[1,4,6,7]$ proved the linking between companies' green brand and performance. The authors Mourad M., Ahmed Y. S., Pflanz, Patterson P. G., Spreng, R. A. in the papers $[10,14,15]$ proved that companies with a high level of green reputation are more attractive for foreign green investors. Thus, the finding showed that green branding is a new research direction which contributes the systematization and consolidation in the framework to attract additional green investment for company's development.

The purpose of the article is systematization of the main features, drivers and parameters of the green brand with the purpose of allocation options for companies to attract additional green investment.

Results and discussion. The green passion and branding have become the most significant factor which has an impact on the efficiency of the company's marketing program. In this case, communication with the main stakeholders is a key element to identify the options to improve the promotion of the company's green brand green-focused their thoughts and feedbacks. It should be noted, that providing the green investment policy for companies with the interconnection of green marketing strategies allow getting the unfair competitive advantages and exploring new markets in order to enhance their market shares. According to $[3,4]$ in those cases companies should adopt the branding strategies of green products in their relation to green marketing efforts. Among the green brands, green brand equity can be created by its three drivers green brand image, green brand trust and green satisfaction (Figure 1).

Green brand image is helpful in creating green brand equity with the mediating role of green trust and green satisfaction (figure 1). Moreover, companies should implement long term green strategies in order to develop green brand equity and its antecedents. Green brands defer from each other by the degree of integrated green issues [7]. Therefore, there are three categories of "greenness" [15]:

- green as a core value;

- green integrated with core values;

- green values as the guarantee. 

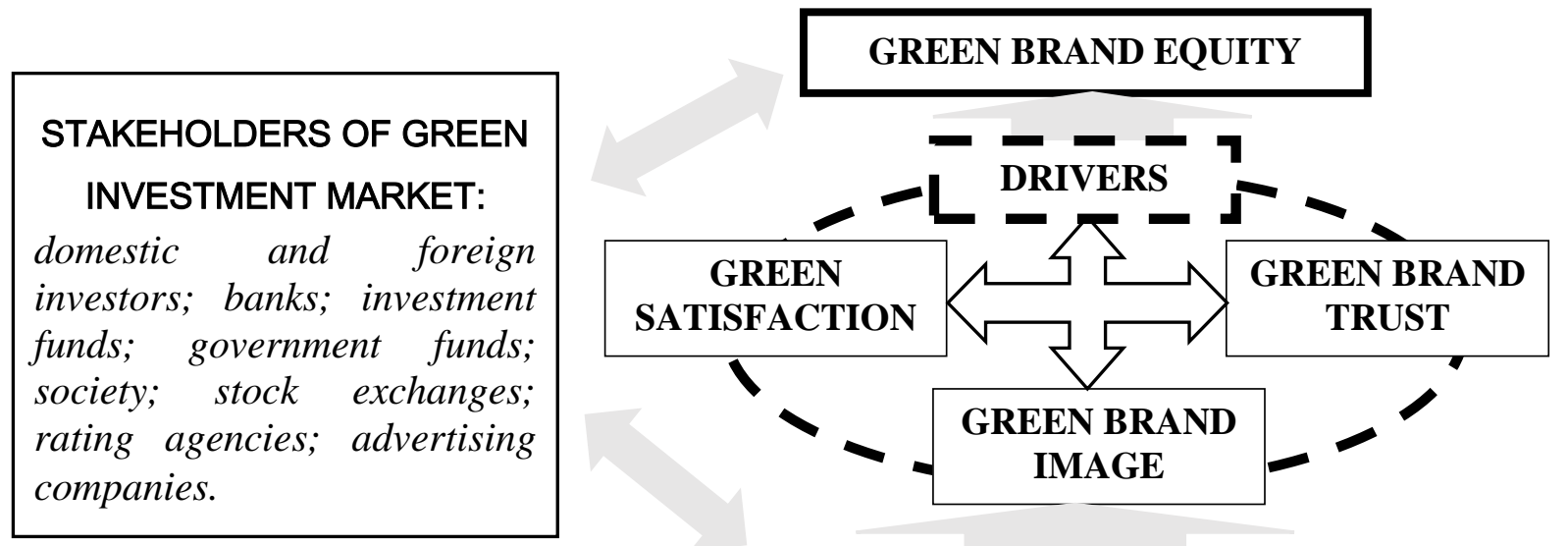

GREEN MARKETING INSTRUMENTS:

\begin{tabular}{|c|c|}
\hline MODERN & TRADITIONAL: \\
\hline $\begin{array}{l}\text { ambient media, crazy } P R, \text { storytelling, } \\
\text { sensitive marketing, identity marketing, } \\
\text { inbound- marketing, shockvertisin and co- } \\
\text { marketing }\end{array}$ & 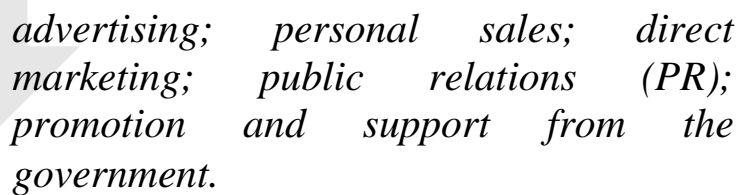 \\
\hline
\end{tabular}

Figure 1. Drivers of green brand equity in the framework of the green market concept Source: developed by the authors

The other classification, by Landor Associates, Newsweek, and Penn Schoen Berland, indicated four groups of green brands in [5]: unsung heroes; free passers; losers; winners. The detail explanation types of the green brand are presented in Table 1.

Table 1.

Classification of green brand

\begin{tabular}{|c|l|}
\hline TYPE & \multicolumn{1}{|c|}{ EXPLANATION } \\
\hline Unsung Heroes & $\begin{array}{l}\text { brands that conduct strong green practice, but with insignificant public } \\
\text { awareness }\end{array}$ \\
\hline Free Passers & $\begin{array}{l}\text { brands that conduct limited green practice, but with the distant brand echo } \\
\text { that drives green reputation }\end{array}$ \\
\hline Losers & $\begin{array}{l}\text { brands that conduct limited green practice, with public recognition of the } \\
\text { limitations }\end{array}$ \\
\hline Winners & brands that conduct strong green practice that is recognized in public \\
\hline
\end{tabular}

Source: developed by the authors on the basis of [5]

According to [1] the main advantage of creating green brand equity is the definite increase in environmental awareness, which companies can exploit for competitive advantage through the deployment of their products in different markets. In that case, the companies would have additional opportunity to attract investment for their activity connected with resource saving, recycling, greening etc. Thus, findings proved the relationship between the company's performance and green brands in both directions. Positive green brand leads to increasing the level of trust to the company among the stakeholders. As a consequence, the company could attract additional financial recourses to the implementation of the green goals. However, if the company doesn't implement the green goals due to the lack of finance couldn't develop a positive green brand. In this case, companies don't have a huge range of options to attract additional finance recourses. The linking between green brand, goals and companies' performance are shown in Figure 2. 


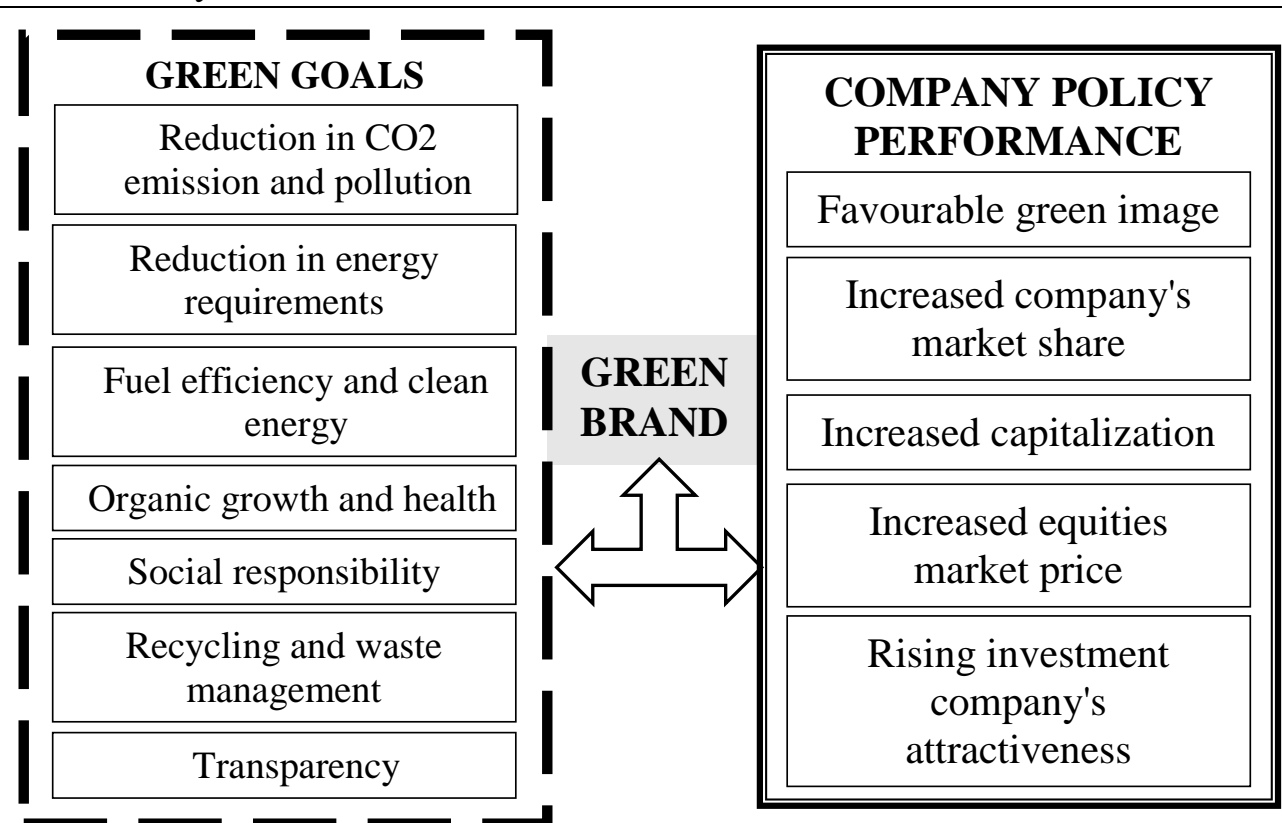

Figure 2. Linking between sustainability, green brand perception

\section{Source: developed by the authors} and company policy performance

Noted, the findings showed, that developing the green brand should be based on the following principals: transparency, publicity, complexity, diversification. The obtained results of investigations allow making conclusions that a huge range of companies avoiding the transparency principals during the creation of own green brand. It leads to decreasing the trust level among stakeholders to the brand green as usual meaning. Most of those companies used greenwashing. It means, that companies pay more the promotion program of green goal than really have spent money on improving ecological parameters of operations in practice. In this case, the companies could lose more money due to the decreasing of reputation. As the example, the scandal with $\mathrm{CO} 2$ emissions at Volkswagen Companies. According to the estimation, the reputation loses was more than billions of dollars.

The issue of using greenwashing could be overcome through the publication of the nonfinancial reports by the companies on a regular basis. In addition, it should be obligatory and controlled by the government.

The scientists Muhammad Zubair Tariq in the paper [11] allocated the principals of green brand developing as follows:

1. Companies should use true and fair environmental claims in their advertisements in order to increase sale and profits and mobilize green investments.

2. Organizations should create awareness regarding environmental protection and sustainability among existing and potential customers and must manufacture green products at lower price and high quality to satisfy the green needs of customers.

3. Companies should develop green projects, promote green investment.

4. Companies must design strong brand development and brand awareness strategies in order to create and maintain the image of "being green" in target customers.

5. The government should devise plans and campaigns regarding environmental protection and sustainability in public in order to keep safe the boundaries of the country from global warming [11].

A company with an eco-friendly brand in its portfolio could also have green securities. Green brand positioning can be utilized not only as a tool in gaining a company's competitive advantages but also as an instrument of attracting investment for green projects.

The results of the analysis showed that green investment market has been developed from year to year which proved the profitability of green investment and justified the promotion of green brand by the companies. In 2018 compared to 2010, the S\&P 500 Environmental \& 
Socially Responsible Index and Dow Jones Sustainability World 80 Index had a significant increasing (figure 3). Thus, according to the official reports of S\&P Dow Jones Sustainability the companies' value listed by abovementioned indexes have a higher added value than traditional companies [19].

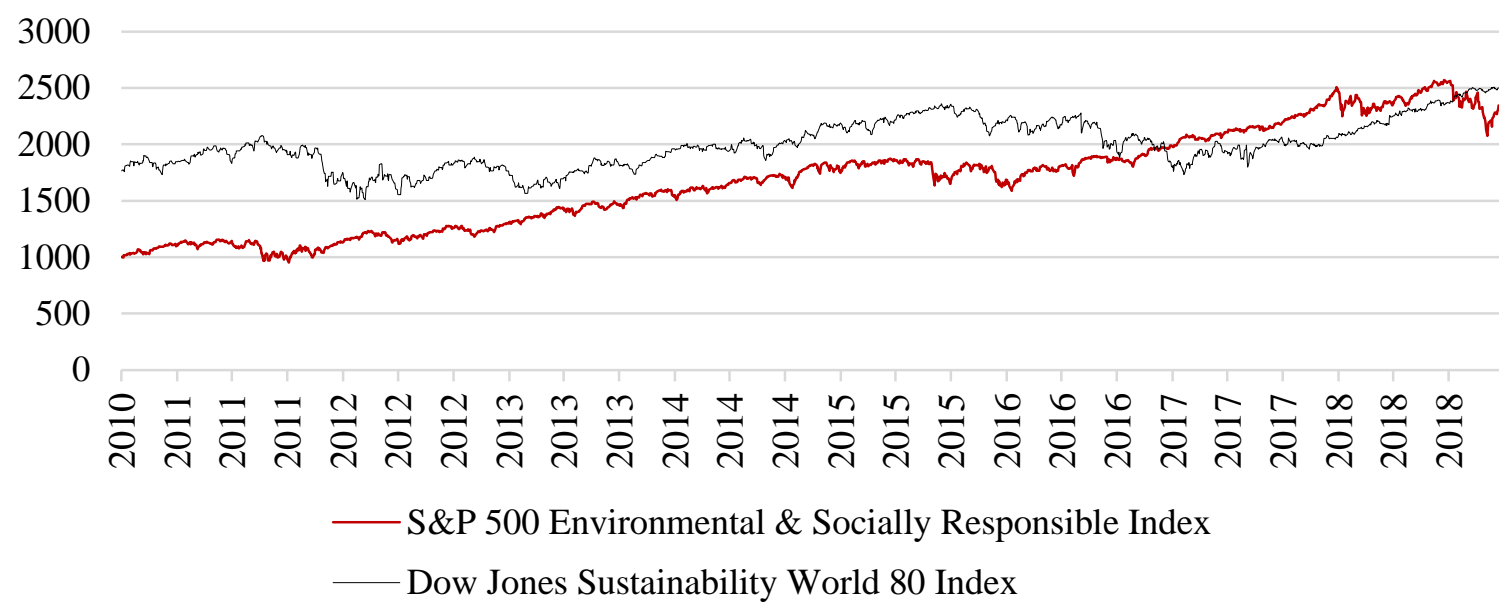

Figure 3 Dynamic of green stock indexes 2010-2018 years

Source: developed by the authors on the basis of [19]

One of the main parameters of the green brand is brand positioning. Thus, during the developing of the green brand strategies the company's management should taking to account the main target group. In this case, the different types of brand positioning could be allocated: functional, green and emotional positioning. In Table 2 the compilation of the main types of green brand positioning is presented.

Table 2

Green brand positioning

\begin{tabular}{|c|l|c|}
\hline TYPE & \multicolumn{1}{|c|}{ MEANING } & AUTHORS \\
\hline Functional positioning & $\begin{array}{l}\text { Mediator to convey environmentally- } \\
\text { related messages to consumers }\end{array}$ & $\begin{array}{c}\text { Hartmann et al., } \\
2005\end{array}$ \\
\hline Green positioning & $\begin{array}{l}\text { The important factor to support green } \\
\text { branding strategy }\end{array}$ & Patrick et al., 2005 \\
\hline Emotional positioning & $\begin{array}{l}\text { Transfer effective contents of the brand } \\
\text { attribute to gain consumers' emotional } \\
\text { responses }\end{array}$ & Matthes et al., 2013 \\
\hline
\end{tabular}

Source: compiled by the authors on the basis of $[8,13,9]$

The brand is a category which influence or could determine the company's value. Consequently, it is necessary to tell about the concept of perceived value $[12,18]$. The brand perceived value is based on the hypothesis of brand equity and refers to the purchase validation, fairness, and appropriation of clients. Hence, customers always pay the costs for products and compare them with the benefits of their brand products [2]. Based on the concept of Patterson and Spreng [14], and Chen and Chang [4], green brand is an overall assessment of the perceived value of a product or service by the customer, and the net profit between what is perceived and what customers are offered based on environmental concerns, expectations, and needs of a sustainable green product. According to studies, nowadays, consumers believe that the use of environmentally friendly products offers many advantages compared to conventional products [8]. It could be considered that the perceived value of a green brand is positively related to green bond equity, it will promote companies' capitalization, rising securities market value.

The findings allow making the conclusion that green branding could highlight company among other competitors through the developing of unique product or service which associate as 
eco-friendly. In this case, with the purpose to attract consumers' attention the companies should pay attention to the following aspects:

- the target group should understand the green features and benefits from using such a product;

- accessibility to the information which proved the greening parameters of the product;

- differentiation of promoting instruments corresponding to the stakeholders' interests.

It should be noted, that companies should avoid using greenwashing and in practice demonstrate the implementation of green innovations which proved greening forces of the company.

Conclusion. Thus, the obtained results showed that if companies try to attract the additional green investment, it is recommended to integrate green brand mental impression and eco-friendly products for upgrading strategy and marketing communications. Therefore, it can create a successful green image in the minds of consumers. Since eco-friendly products are usually priced at a premium in comparison to the conventional products, it is extremely important for the companies to ensure that along with green attributes, the functional performance of their brands is at least equal if not better than the conventional products in the same category to generate substantial green brand equity. Viewed from another perspective, when the conventional product attributes of a green product are at par with competing brands, the eco-friendly attributes will act to serve as the source of additional value that could generate consumer preference towards such brands and will create the willingness to invest in the green project. For further investigation, it is necessary to investigate the linking between green brand perceptions and companies' performance in the stock market which will be proved by the empirical results.

\section{References}

1. Ailawadi, K. L., \& Keller, K. L. (2004). Understanding retail branding: Conceptual insights and research priorities. Journal of Retailing, 80, 331-342.

2. Bolton, R. N., \& Drew, J. H. (1991). A longitudinal analysis of the impact of service changes on customer attitudes. Journal of Marketing, 55(1), 1-9.

3. Chen, Y. S. (2010) The drivers of green brand equity: green brand image, green satisfaction, and green trust. Journal of Business Ethics, 93(2), 307-319.

4. Chen, Y. S., \& Chang, C. H. (2012). Enhance green purchase intentions. Management Decision, 50, $502-520$

5. Danciu, V. (2015). Successful Green Branding, a New Shift in Brand Strategy: Why and how it works. The Romanian Economic Journal, 56, 47-64.

6. Doszhanov, A., \& Ahmad, Z. A. (2015). Customers' intention to use green products: The impact of green brand dimensions and green perceived value. SHS Web of Conferences, 1-16.

7. Grubor, A. Milovanova O. (2017). Brand strategies in the era of sustainability. Interdisciplinary Description of Complex Systems, 15(1), 78-88

8. Hartmann, P. Ibanez, V. A. Sainz, J. F. (2005). Green branding effects on attitude: functional versus emotional positioning strategies. Marketing Intelligence \& Planning, 23 (1), 929.

9. Matthes, J. Wonnerberger, A. Schmuck, D. (2013). Consumers' green involvement and the persuasive effects of emotional versus functional ads. Journal of Business Research, 67(9), 1885-1893.

10. Mourad, M., \& Ahmed, Y. S. (2012). Perception of green brand in an emerging innovative market. European Journal of Innovation Management, 15(4), 514-537.

11. Muhammad Zubair Tariq (2017) Green Advertisement and Green Brand Awareness on Green Satisfaction with Mediating Effect of Buying Behavior. Journal of Managerial Sciences. Volume VIII Number 2. P. 274-289

12. Parasuraman, A., \& Grewal, D. (2000). The impact of technology on the quality-value-loyalty chain: A research agenda. Journal of the Academy of Marketing Science, 28, 168-174.

13. Patrick, H., Ibanez, V.A., Sainz, F.J.F. (2005). Green branding effects on attitude: functional vs emotional positioning strategies. Marketing Intelligence and Planning, 23 (1), 9-30.

14. Patterson, P. G., \& Spreng, R. A. (1997). Modelling the relationship between perceived value, satisfaction and repurchase intentions in a business-to-business, services context: An empirical examination. International Journal of Service Industry Management, 8, 414-434.

15. Pflanz, S. (2014). Sustainable Brand - The chance for competitive differentiation. In German. Retrieved from: http://www.marketingboerse.de 
16. Pimonenko T. (2018). Ukrainian Perspectives for Developing Green Investment Market: EU Experience. Economics and Region, 4 (71), 35-45.

17. Pimonenko T., Lushyk K. (2017). Green investing: EU experience for Ukraine. Bulletin of Sumy State University. Economy Ser., 3, 61-67.

18. Sarkar, N.A.: Green Branding and Eco-Innovation for Evolving a Sustainable Green Marketing Strategy. Asia-Pacific Journal of Management Research and Innovation, 8(1), 39-58, 2012,

19. S\&P Dow Jones Indices LLC. (2018). S\&P 500 Environmental \& Socially Responsible Index. Retrieved from: https://us.spindices.com/indices/equity/sp-international-environmental-sociallyresponsible-index

20. Sweeney, J. C., Soutar, G. N., \& Johnson, L. W. (1999). The role of perceived risk in the quality-value relationship: A study in a retail environment. Journal of retailing, 75, 77-105.

\section{Пімоненко Тетяна,}

кандидат економічних наук, доцент,

Сумський державний університет

Чигрин Олена,

кандидат економічних наук, доцент,

Сумський державний університет

Люльов Олексій,

доктор економічних наук, доцент,

Сумський державний університет

\section{ЗЕЛЕНИЙ БРЕНДИНГ ЯК ДРАЙВЕР РОЗВИТКУ РИНКУ ЗЕЛЕНИХ ІНВЕСТИЦІЙ}

Проблема. Зростаюче усвідомлення екологічних проблем у суспільстві провокує компанії переорієнтувати свою діяльність відповідно до зелених потреб споживачів. Бажання інвесторів інвестувати в зелені цілі виправдовує розвиток $і$ просування зелених зображень $i$ зеленого бренду компаніями. Позитивна зелена марка компанії та високий рівень лояльності споживачів дозволяють залучати додаткове фінансування як «зелене» інвестування у розвиток компанії. Компанії, охоплені зеленими фондовими індексами, мають більшу додану вартість. Досвід країн СС показав, що зелені інвестииї̈ є новим перспективним ринком, який характеризується швидким зростанням з року в рік.

Метою статті є систематизаиія основних ознак, драйверів і параметрів зеленого бренду з метою вибору підприсмиями варіантів залучення додаткових зелених інвестицій.

Результати. Відзначено, що поточні економічні та політичні конфлікти негативно впливають на бренд та імідж краӥни. Це призводить до зменшення інвестичійного клімату крайни, що обмежує розвиток національного ринку зелених інвестицій. Компанії не мають величезних можливостей для залучення додаткових зелених інвестицій у свій розвиток. У ивому випадку необхідно розробити та впровадити ефективний механізм просування зеленого бренду як на рівні країни, так і на рівні компанії.

Наукова новизна. Авторами виділено основні риси зелених інвестицій, які слід враховувати nід час розробки маркетингової програми з просування зеленого бренду компанії. Визначено основні підходи до визначення сенсу зеленого бренду. В роботі зелений бренд витлумачено як унікальні символи, знаки, слова або комбінації з них, які розвинули зелену уяву про компанію, операції якої відповідають иілям сталого розвитку. Виділено головні драйвери зеленого бренду таким чином: екологічно чистий бренд, зелена довіра і зелене задоволення. Екологічна марка має посередницьку роль між зеленим довірою та зеленим задоволенням.

Висновки. Авторами підкреслено, що використання маркетологами зеленого камуфляжу призводить до величезної втрати репутаиії. Крім того, зелений камуфляж знижує рівень довіри до зеленого бренду серед зацікавлених сторін ринку зелених інвестицій. Автори запропонували вирішити вищезгадану проблему через публікацію у вільному доступі нефінансової доповіді компанією на регулярній основі. Крім того, вона повинна бути обов'язковою і контролюватися урядом. У роботі авторами визначені теоретичні основи взаємозв'язку між стійкістю, сприйняттям зеленого бренду та ефективністю політики компанії.

Ключові слова: інвестииї; маркетинг; зелені інвестиції; заиікавлені сторони; бренд; просування; додана вартість. 